\title{
Late Gzhelian pteridosperms with callipterid foliage of the Donets Basin, Ukraine
}

\author{
Natalya Boyarina \\ Acta Palaeontologica Polonica 55 (2), 2010: 343-359 doi: http://dx.doi.org/10.4202/app.2009.0020
}

Eight species of pteridosperms with callipterid foliage belonging to four genera are described from the upper Gzhelian of Donets Basin. The fossils indicate that the fronds of the callipterids belonging to the genera Lodevia, Dichophyllum, and Raminervia are bipartite in the upper part and are distinguished by the morphology of the penultimate order pinnae. The main diagnostic character of callipterid species with dissected pinnules is the shape of the pinnule segments. The degree of segmentation of pinnules and their size are considered to represent intraspecific variability expressing the heteroblastic development of the foliage. The taphonomical features of the plant remains and facies interpretations of the plant-bearing strata, including floodplain, floodplain-lacustrine and lacustrine deposits, indicate that the callipterids were dominant elements of the floodplain vegetation in the late Gzhelian.

Key words: Pteridospermopsida, Peltaspermales, foliar morphology, frond architecture, palaeoecology, Gzhelian, Donets Basin.

Natalya Boyarina [nboyarina@mail.ru], Institute of Geological Sciences of the Ukrainian NAS, Gonchara 55-b, 01601 Kiev-54, Ukraine.

This is an open-access article distributed under the terms of the Creative Commons Attribution License (for details please see creativecommons.org), which permits unrestricted use, distribution, and reproduction in any medium, provided the original author and source are credited. 